\title{
Los albores de la meta-memoria histórica en el teatro español
}

Sirviéndome de las teorías de Jacques Derrida, Cathy Caruth, Linda Hutcheon, Jan Assman y Pierre Nora, entre otros, examino las maneras en las cuales tres dramaturgos de distintas realidades - un autor consagrado, Antonio Buero Vallejo; un joven prometedor, Jerónimo López Mozo; y un exiliado, José Antonio Rial - dieron pie a lo que denomino la meta-memoria histórica: la confrontación manifiesta y el cuestionamiento teatral de las divergencias, sombras y verdades polifacéticas asociadas con las memorias colectivas simultáneas y posteriores a la Guerra Civil española. Concretamente, los dramaturgos utilizan la memoria explícita - expresada mediante la anacronía, la metateatralidad, y/o el recurso a personajes que son muertos vivientes -, con el fin de resaltar la continua reconstrucción de la historia colectiva. En las postrimerías del franquismo, sus tres piezas respectivas, El tragaluz (1967), Guernica (1969) y La muerte de García Lorca (1969), entablan un diálogo intertextual, fragmentado e indeterminado entre el pasado y el presente. Estas tres obras auguran una estética que cobra cada vez más relieve en el teatro español, a medida que se ha ido tanteando dicho pasado traumático en España durante las últimas cuatro décadas.

En sus escritos sobre los que vivieron el Holocausto, Ernst van Alphen pone de relieve cómo las víctimas del trauma histórico fueron privadas de su libre albedrío y transformadas en "objetos de la historia". Según él, para aliviar esta secuela, es preciso que los afectados aprendan a contar su historia de manera que se conviertan nuevamente en "sujetos de historia" (24-38). De acuerdo a Ulrich Winter, una víctima de una tragedia colectiva debe buscar su vida "en el mundo al que vuelve" mediante "una demanda de reconocimiento de existencia dirigida al oyente" (261). De ahí que la recepción de su testimonio es crítica para su restitución e intervención activa en la memoria histórica. Es por ello que ha sido esencial sacar a la luz recuerdos recónditos o marginados por la tergiversada historia española durante la época de la dictadura franquista. Durante las cuatro décadas del franquismo fue complicado perfilar otras identidades sociales, o "contramemorias": retentivas arrinconadas y suprimidas a nivel público (Zemon Davis y Starn 2). Estas memorias alternativas fueron limitadas, por lo general, a lo que el egiptólogo alemán Jan Assman acuña como "la memoria comunicativa", refiriéndose a la memoria cotidiana transmitida 
por tres o cuatro generaciones de forma oral (Olick et al. 213). Tergiversaciones, fantasías y verdades selectivas, también se entretejen con los recuerdos auténticos a la hora de recordar (Ricoeur 67).

Como señala Cathy Caruth, las memorias precarias de las víctimas, siempre a punto de desvanecerse, emergen a través del testimonio oral o escrito, además de la (re-)representación de sus propias desapariciones en los mismos sitios en los que primero ocurrieron (xi). Fue Pierre Nora quien denominó a estos sitios, objetos, cuerpos o lugares simbólicos como "lugares de memoria", por lo que los textos teatrales que se escribieron en el exilio y la Península luego de finalizada la Guerra Civil Española en 1939 constituyen "lugares de memoria en depósito" (7-24). Al ser su destino último el escenario, estos textos, representantes de la memoria pasiva, han pretendido en muchas ocasiones, aunque infructuosamente, convertirse en memoria activa.

Según Jan Assman, la memoria activa recoge "el pasado en el presente" (Olick et al. 335), un proceso que contribuye a lo que el sociólogo francés Maurice Halbwachs denomina la memoria colectiva: los recuerdos retenidos por un grupo social sobre un pasado particular, así como el aprendizaje, los valores y el sentido de identidad basados en esa evocación (40). No obstante, como recalca Linda Hutcheon, las huellas del pasado son conocidas en el presente mediante el discurso selectivo (97), por lo que devienen verdades pluralistas del pasado (109) con una preocupación explícita por su recepción (115). El montaje de dichas piezas ha contribuido a la comparación, revisión y reivindicación de evocaciones históricas por parte de espectadores, lectores, dramaturgos, actores, directores, técnicos de sonido, luminotécnicos, utileros, etc. Todas estas personas, al participar en el rito teatral, hacen de homo actans, en tanto que escenifican cierta reconstrucción de las memorias colectivas españolas, insuflando vida a memorias latentes para que puedan integrar nuevamente las memorias históricas en perpetua revisión (Winter y Sivan 9-10).

A juicio de la teórica cultural alemana Aleida Assman, esta canalización de la memoria histórica se denomina "metamemoria" social: un "archivo" de recuerdos olvidados o apartados que ofrece un contrapeso al impulso restringido y limitado de la memoria activa, amén de la posibilidad de contrastar y examinar varias memorias, brindando así una perspectiva retrospectiva de la historia (Olick et al. 337). "Meta", cabe puntualizarlo, se refiere a la autoconciencia de la palabra que prefija. Según el diccionario de la Real Academia Española, significa "después de, entre, con o acerca de". Consiste en la interacción, como asevera Jan Assman, "entre" la perspectiva actual y dicha potencialidad del "archivo" de memoria. El proceso interactivo entre el pasado "contemporáneo", la 
cultura y el grupo, es denominado por Assman memoria cultural. Es, por así decirlo, el intercambio reconstructivo y el carácter autorreflexivo de la memoria lo que delimita la identidad social de una colectividad. El concepto que Linda Hutcheon acuña, "metaficción historiográfica", sostiene que el arte posmoderno se caracteriza, asimismo, por la transparencia de su referencialidad histórica (110).

Ahora bien, la censura franquista detrás de toda pieza y dramatización teatral resultó altamente dañina para esta reciprocidad que requiere una evolución libre de la memoria cultural, sobre todo antes de 1966, año en el que se aprobó la Ley de Prensa e Imprenta. Esta legislación derogó la censura previa y decretó un sistema de "consultas voluntarias" por parte de los editores (Muñoz Cáliz 20). Antes de 1966, como consecuencia del cercenamiento de la gran mayoría de los montajes y obras testimoniales que versaban sobre la conflagración de 1936, se dio una escasez de textos teatrales escritos, y especialmente de obras estrenadas, sobre aquel trauma colectivo. De igual modo, la autocensura y el exilio incidieron considerablemente en la dramaturgia española. A pesar de esto, contamos con las obras de algunos escritores en el exilio - a saber Max Aub, Pedro Salinas y Rafael Alberti -, y las de otros dramaturgos dentro de la Península, como Antonio Buero Vallejo y José Martín Recuerda.

En las postrimerías del franquismo, tres dramaturgos españoles de distintas realidades - un autor consagrado, Antonio Buero Vallejo; un joven prometedor, Jerónimo López Mozo; y un exiliado, José Antonio Rial dieron pie al uso de lo que yo llamo la meta-memoria histórica: la confrontación y el cuestionamiento teatrales de las divergencias, sombras y verdades polifacéticas de las memorias colectivas relacionadas con el periodo de la Guerra Civil española y con el de tiempos posteriores. En sus piezas respectivas, escritas entre 1967 y 1969, Buero Vallejo, López Mozo y Rial otorgan un rol activo al público en la puesta en escena, pues este coteja y (re)forma las memorias sociales encarnadas sobre el escenario. Concretamente, los tres dramaturgos se sirven de la memoria explícita y teatral - expresada mediante la anacronía, la metateatralidad, y/o el recurso a personajes que son muertos vivientes -, con el fin de entablar un diálogo no-linear y fragmentado entre distintos momentos del pasado y del presente. Representan una continua revisión de la memoria cultural en sus respectivas piezas: El tragaluz (1967), Guernica (1969) y La muerte de García Lorca (1969).

La primera obra española en servirse del recurso de la meta-memoria histórica, en confrontar teatralmente la memoria colectiva de una época con otra, fue El tragaluz, escrita y estrenada en 1967, dos años antes que Guernica y La muerte de García Lorca. En 1969, Francisco Umbral calificó El 
tragaluz de este modo: "Es, finalmente, la obra más importante que se haya hecho en teatro - y quizá también con respecto a la novela e incluso el ensayo - sobre la guerra civil de España" (Buero Vallejo 189). Habría que agregar que actualmente sigue siendo una de las mejores obras escritas sobre la Guerra Civil. Es la primera pieza en que Buero Vallejo se refiere directamente a la contienda que tuviera que vivir siendo muy joven.

La obra es, por tanto, temáticamente atrevida y sumamente innovadora con respecto a su estilo. Como manifiesta Luis Iglesias Feijoo, "El Tragaluz puede ser calificada en cierto modo de obra histórica 'al revés' o a posteriori: el presente se ilumina en ella desde el futuro ficticio" (17). La pieza es una prolepsis que consiste en un experimento utópico de ciencia ficción llevado a cabo por dos investigadores del lejano siglo XXX: Él y Ella. Estos personajes genéricos del futuro han "descubierto" una manera de acceder a una memoria social "total", rescatando del olvido fantasías, imágenes, sonidos y hasta modos de ver de cada persona que ha vivido antes de Él y Ella. Efectivamente, con su tecnología del futuro, han podido restablecer artificialmente, "mediante el movimiento de los labios", varios sonidos que se consideraban "irrecuperables". A la par, "algunas palabras procedentes del tragaluz se han inferido igualmente mediante los cerebros electrónicos" (Buero Vallejo 67).

El diálogo que da pie a la anécdota escenificada hace hincapié en la capacidad futurística y utópica de (re-)representar y reconstruir la memoria cultural, no solo de lo dicho, hecho y escrito, sino también la de los pensamientos particulares:

Él. - Oiréis, además, en algunos momentos, un ruido extraño. [No pertenece al experimento y] es el único sonido que nos hemos permitido incluir por cuenta propia.

Ella. - Es el ruido de aquella desaparecida forma de locomoción llamada ferrocarril [y lo hemos recogido de una grabación antigua]. Lo utilizamos para expresar escondidas inquietudes que, a nuestro juicio, debían destacarse. Oiréis, pues, un tren; o sea un pensamiento. (68)

En este ejercicio de montar la memoria cultural por medio de su reconfiguración, confrontación y análisis, se incorpora incluso "la acción más oculta o insignificante", pues "el misterioso espacio" de la memoria cultural "todo lo preserva" y "cada suceso puede ser percibido desde algún lugar". Esto se logra, inclusive, "a veces, sin aparatos, desde alguna mente lúcida", como la de un poeta (99-100). He aquí el elemento metateatral y la influencia pirandelliana en El tragaluz. ${ }^{1}$ Él y Ella observan y plasman las realidades de antaño desde diferentes puntos de vista, percibiéndolas y 
torciéndolas a su juicio. En cierto sentido, se asemejan a dramaturgos, quienes, de igual modo, tergiversan lo contemplado para convertir memorias en historias escenificables. Estos "investigadores" de ciencia ficción han hecho "vivir" en el escenario todas estas retentivas históricas a la espera de quien las recoja.

Los actores-personajes de la anécdota que el espectador observa son, en realidad, simples "fantasmas", o recuperaciones del pasado, captados por su tecnología:

Él. - Estáis presenciando una experiencia de realidad total: sucesos y pensamientos en mezcla inseparable.

Ella. - Sucesos y pensamientos extinguidos hace siglos.

Él. - No del todo, puesto que los hemos descubierto. (Por Encarna.) Mirad a ese fantasma. ¡Cuán vivo nos parece! (91-92)

Como observa Josette Féral, el cuerpo del actor teatral "no representa sino que recrea, revive, reconstruye, imagina y performa" (25-26), de modo parecido a los fantasmas de la obra de Lacan - en los cuales convergen lo imaginario, lo simbólico y lo real (Fink 3) - y los espectros visibles, o "proyecciones" imaginarias de las "apariciones desaparecientes" de Jacques Derrida. Estos últimos vuelven repetidamente en pos de una justicia escurridiza (Derrida 117). De acuerdo con Brian Rotman, tal "yo" actoral, escindido y desdoblado, es lo que favorece el fenómeno de los aparecidos en el género teatral (119). El espectro patentiza, en definitiva, la imbricación del ayer y del hoy en una puesta en escena efímera.

Volvemos con Él y Ella, como observa Francisco Ruiz Ramón, "hacia nuestro presente" (371). En este "caso particular respecto al teatro histórico", Mariano de Paco ha advertido la "cuidada plasmación" de lo que él mismo ha llamado "perspectivismo histórico: el espectador establece la relación de su presente con un futuro que tiene lugar en el drama" (14-15). El público se percata, por tanto, de que su vida también es susceptible de ser investigada por vía de la memoria venidera, como lo pone de manifiesto Ella al dirigirse a la audiencia:

Si no os habéis sentido en algún instante verdaderamente seres del siglo veinte, pero observados y juzgados por una especie de conciencia futura; si no os habéis sentido en algún otro momento como seres de un futuro hecho ya presente que juzgan, con rigor y piedad, a gentes muy antiguas y acaso iguales a vosotros, el experimento ha fracasado. (Buero Vallejo 166) 
Este personaje recalca además que, "reasumir el pasado vuelve más lento nuestro avance, pero también más firme". Sin embargo, los investigadores no solo rescatan el pasado con su tecnología futurística, sino que también lo heredan y reasumen con todos sus defectos: "Nos sabemos ya solidarios, no sólo de quienes viven, sino del pasado entero. Inocentes con quienes lo fueron; culpables con quienes lo fueron" (147). En este sentido, la recuperación de su pasado les ayuda a perfilar todas las facetas de su identidad social.

Esta posibilidad lejana de hacer que el pasado viva realmente ante nosotros, de ponernos cara a cara con nuestros antepasados y de, en fin, juzgarlos, trae repercusiones significativas para el espectador. $Y$ es que este, en realidad, se desdobla. Por una parte, el público está convocado a analizar, en la línea brechtiana, un resultado - el trauma de una familia anónima durante el franquismo - del "experimento" que Él y Ella recuperan sobre el escenario, produciendo así un efecto metateatral. Esta anécdota rescatada tiene lugar en el pasado reciente de la audiencia, o en la actualidad si se refiere al público original que acudió al estreno en 1967. Por otra parte, el experimento simboliza la probabilidad de que la historia juzgue a los que están presentes en el porvenir, por lo que el público es, en efecto, desplazado al futuro lejano de los investigadores. Los espectadores son, a la vez y de modo paradójico, jueces futurísticos de su propia vida y de su propio tiempo. A través de la fantasía teatral, comparten la contemporaneidad de Él y Ella en el siglo XXX, y su capacidad de atestiguar una recreación "viva" del pasado. En cierto sentido, la audiencia asiste a su propia muerte.

El espejo recíproco entre el cual la audiencia y el escenario se ven sería un modelo de la "participación o 'inmersión' psicofísica del público" que busca Buero continuamente (Medina Vicario 51). El público, por lo demás, resulta ficcionalizado en sentido doble, tanto en función de su integración en el futuro de Él y Ella, como por su implicación en la realidad reciente de la anécdota ficticia escenificada. Por añadidura, los espectadores advierten la decadencia de su circunstancia político-social, de su país - España no existe en el Siglo XXX -, y de su "tosco modo de hablar", más allá de que los investigadores futurísticos balbuceen la jerga del siglo XX durante el experimento. De esta manera se acentúa lo efímero de nuestras perspectivas sobre el pasado, incluido el patriotismo que aupaba el régimen franquista en su afán legitimador, a la vez que se resalta lo imprescindible de nuestro legado para aspirar a un porvenir más sano.

Pero no hay que perder de vista que, al igual que el propio dramaturgo - y cualquier persona que medie en la memoria social -, Él y a Ella seleccionan las historias que recuperan y escenifican. Son una suerte de 
memorias dentro de la memoria cultural española. ${ }^{2}$ Por ello, resulta significativo que los investigadores hayan escenificado una anécdota que tiene lugar a finales del franquismo. A través de la rivalidad entre dos hermanos - Vicente, el oficinista oportunista, y Mario, el observador sensible - se hace una prolongación simbólica de la Guerra Civil, y del mito cainita de las dos Españas. Las recurrentes discusiones entre los dos hermanos en 1967 desentierran paulatinamente una memoria latente y fatídica que data de 1939: la muerte de su hermanita, Elvirita, de dos años. Buero va aludiendo a la verdad de esta muerte a lo largo de El tragaluz, de forma que el espectador va desgranando los hechos: al terminar la Guerra Civil, toda la familia intentaba subir al tren de regreso a Madrid y sólo Vicente, el hermano mayor y el más fuerte, logró hacerlo, llevándose consigo la única bolsita de comida y dejando así desamparada a toda su familia. A los pocos días de quedar atrás con sus padres y Mario, su hermana, Elvirita, murió de hambre.

Por mucho que la familia intente sepultar el recuerdo lúgubre de dicha tragedia, esta no deja de emerger en la actualidad - como premonición de la futilidad del disimulo de ese pasado fatídico por parte de las autoridades españolas durante la transición política -. Por otro lado, estos hermanos, estancados en 1939, continúan perpetuando sus respectivos roles de verdugo y víctima. ${ }^{3}$ Se da así un altercado entre Vicente, el jefe de una editorial prestigiosa, y su hermano Mario cuando este procura evitar, en vano, las injusticias que aquel está cometiendo con un excelente escritor izquierdista, denominado Beltrán - símbolo de los autores maltratados en virtud de su orientación política. Al procurar justificarse ante su humilde secretaria, Encarna, Vicente declara que "Beltrán, por ejemplo, escribe a menudo: 'Fulana piensa esto, o lo otro...' Un recurso muy gastado" (Buero Vallejo 73). Pero al censurar el uso tradicional del narrador omnisciente, Vicente critica, sin saberlo, la perspectiva del futuro lejano de Él y Ella, dada a conocer por la suerte de tecnología omnisciente que estos investigadores pasan a describir como: "Un ojo implacable nos mira, y es nuestro propio ojo. El presente nos vigila; el porvenir nos conocerá, como nosotros a quienes nos precedieron" (166). La conciencia colectiva de la memoria social que caracteriza a la población del siglo XXX inspira alguna esperanza para el futuro, como asegura Él: "Hoy ya no caemos en aquellos errores" del siglo XX (166). ${ }^{4}$

Enredada, sin quererlo, en esta desavenencia cainita, Encarna también llega a interponerse entre ambos hermanos. Víctima del sistema, Encarna se presta a ayudar a Mario en relación a lo de Beltrán. Paradójicamente, el temor de perder su trabajo posibilita la escenificación de una imagen correspondiente a su futuro como posible prostituta hambrienta en caso 
de volver a caer en penuria. Este destino posible de Encarna, convertido en personaje mudo, entra y sale del escenario según las inquietudes de la secretaria, con lo cual convergen el presente de la anécdota rememorada y un hipotético futuro, cuya verdad ya conocen, irónicamente, Él y Ella.

Pero Encarna también "encarna" la memoria de Elvirita, ya que tiene la edad que esta hubiera cumplido de haber vivido. Aún más, el padre de los hermanos, en su locura, insiste en que ella sea, de verdad, su hija Elvirita. De ahí el doble significado de su presencia como la motivadora del enfrentamiento entre los hermanos y como causante de la repetición de un ciclo. Vicente hará de Encarna otra de sus víctimas femeninas al dejarla embarazada. Mario, por su parte, procurará mitigar los daños ocasionados por su hermano adoptando al bebé. Él ama a Encarna y la rescata de los atropellos de Vicente, resarciendo al que cuando era niño en 1939 no pudo salvar a su hermanita. Aún más, deposita sus ilusiones en la generación venidera al referirse de esta forma al bebé de Encarna: "Quizá ellos algún día, Encarna... Ellos sí, algún día... Ellos..." (169). Esto es un símbolo de la esperanza que puede deparar el porvenir.

Ahora bien, hay otros símbolos teatrales insistentes en El tragaluz que se remontan perpetuamente a la tragedia de 1939. Estos surgen tanto de la locura del Padre, cuya memoria se ha congelado en ese fatídico año - justo en el momento en que aún no había ocurrido la tragedia -, como de la conciencia de Vicente, a quien le cuesta hacer caso omiso del ruido del tren. Vicente percibe a ratos, a pesar suyo, este símbolo de su recuerdo atormentado y persistente de aquel suceso desdichado. Además del efecto sonoro del tren, que alude al papel de Vicente en la muerte nefasta de su hermanita - un rol que repite como un rito - a Vicente también le atrae, como un imán indomable, el "pozo" o cueva de Platón: el semisótano en el que vive su familia apesadumbrada. Pese a los esfuerzos de Vicente por borrar lo ocurrido y contrarrestar el peso de su perturbada conciencia, se ve regresando cada vez más al semisótano de sus padres y hermano, como quien quiere disculparse. Al fin y al cabo, es el sitio en el que vive su padre, como una especie de Segismundo en su prisión y, aunque no lo dice, Vicente desea el perdón de su progenitor.

La locura del Padre, que lo preserva de la verdad nefasta, da pie a un uso singular de la cuarta pared del escenario: simula, a través de algunos efectos sonoros y luminotécnicos, un tragaluz. ${ }^{5}$ Un recurso plástico incorporado ejemplarmente en el teatro de Buero Vallejo, la claraboya, sirve de filtro que deforma, en virtud de su visión fragmentaria, la identidad de los transeúntes que pasan por ella a diario. Como espectadores en un cine, el Padre y Mario proyectan su memoria, preocupaciones y pensamientos sesgados a los paseantes. Observan, 
adivinan e interpretan las vidas de los desconocidos que atisban por el tragaluz. Metateatral y quijotescamente, al ver a una niña jugando cerca del tragaluz, el Padre la llama Elvirita y "solloza inconteniblemente" cuando se marcha. La claraboya simboliza el eterno retorno de la memoria traumática de la muerte de Elvirita. Además, al estar este tragaluz ubicado justo en la cuarta pared, posibilita que los supuestos transeúntes se encuentren entre los espectadores. El público y el escenario se miran, como si la cuarta pared se tratara de un espejo. Buero sugiere así que las memorias de los espectadores y, por ende, las de la época en la que viven, influyen en su recepción de la anécdota representada. De hecho, la audiencia es esencial en el proceso de confrontación y confluencia de la memoria histórica que se escenifica.

En un intento de cambiar el pasado fatídico que condujo a la muerte de su hijita, el Padre incluso confunde la claraboya de su piso en 1967 con la ventana del tren que no alcanzó a subir su familia en 1939. Al mismo tiempo, el Padre percibe el futuro del pasado a la luz de su conocimiento actual - de igual manera que los investigadores - por lo que, exhortando a la Madre y a Mario, les dice: "Vámonos al tren, antes de que el niño [Vicente] crezca" (107). Intenta así evitar la tragedia a toda costa. No obstante, con trágica ironía, Vicente ignora el motivo de la locura de su padre, achacándolo a la senectud en lugar de percatarse de que la memoria del padre se ha estancado en el 1939, justo en el momento en que se acercaba el tren que cambiaría el destino de su familia. Para la anagnórisis de la tragedia, Vicente confiesa su culpabilidad durante su última visita al "pozo" de sus progenitores. Allí, el Padre le apuñala mortalmente con sus tijeras, procurando intervenir, con justicia poética, en el pasado. Desea evitar que su hijo mayor suba al tren con la comida y que, por consiguiente, muera su hijita. Por añadidura, intenta prevenir que su hijo mayor siga produciendo víctimas en la actualidad. La locura del padre en 1967 sirve, entonces, de camino directo a la recreación "en vivo" de la memoria de 1939, y a la confluencia de ambos tiempos dramáticos. El Padre y Mario se convierten en autores, como el propio Buero Vallejo, cuya obra pasa por el tamiz de su memoria de la Guerra Civil. Es más, son visionarios de su época, pues, como rescatistas del olvido, abogan utópicamente por lo imprescindible del recuerdo de cada persona que pasa por la claraboya. El Padre y Mario se parecen no solo a los artistas, sino a los investigadores del siglo XXX: Él y Ella.

Buero retrata ingeniosamente el cuestionamiento formativo de la memoria cultural mediante otro recurso plástico: las tarjetas postales que al Padre le encanta recortar mientras se pregunta "¿Quién es ése?", refiriéndose a los protagonistas de las mismas, del mismo modo en que lo 
hacen Él y Ella con su mirada retrospectiva que empezó a ponerse de moda en el siglo XXII (147). Los investigadores, a pesar de admitir sus limitaciones, proporcionan alguna respuesta a la pregunta incesante del Padre: "Ése eres tú, y tú y tú. Yo soy tú, y tú eres yo. Todos hemos vivido, y viviremos, todas las vidas" (147). La obsesión del Padre por "salvar" a la gente de las tarjetas postales sin duda se relaciona con su afán de rescatar del olvido el recuerdo de su hijita difunta. Por otra parte, no cabe duda de que la cámara fotográfica que origina estas postales también hace de rescatadora del olvido, si bien de un pasado congelado en el tiempo y de un espacio que pasa por el prisma del fotógrafo.

A raíz de sus preguntas retóricas - “¿Quién es ése?” -, de sus manipulaciones de las figuras recortadas de las tarjetas postales, así como del enjuiciamiento y castigo helénico que proporciona a su hijo mayor, el personaje del Padre llega a ser un juez de la memoria que conlleva, en definitiva, una connotación mítica. Efectivamente, es el Padre quien cree decidir quién subirá al tren y quién no, sobre todo entre las personas fotografiadas en sus tarjetas postales, puntualizando "yo tengo que velar por todos y al que puedo, lo salvo" (Buero Vallejo 78). Actúa como un Dios determinando qué difuntos pueden subir al paraíso y cuáles no. Tal alcance de este personaje patriarcal manifiesta la intertextualidad literaria y divina, latentes en la acción dramática de El tragaluz. Se acentúa, además, la disparidad entre el punto de vista sobrehumano a favor de la memoria cultural del Padre y el egocentrismo de Vicente con respecto a la memoria de lo ajeno:

Vicente. - ¿Cómo quiere que sepamos quién es? ¡No es nadie!

El padre. - ¡Sí! ... No está muerto. Y esta mujer que cruza, ¿quién es? (Los mira.). Claro. Vosotros no lo sabéis. Yo, sí. (84)

El anhelo de Mario, el hijo del Padre celestial, de conocer cada rincón de la memoria cultural es, asimismo, un ansia utópica por conseguir la mirada omnisciente de Dios. Paradójicamente, sabemos que esta perspectiva ya será alcanzada por los investigadores del siglo XXX con su tecnología de ciencia ficción.

Además de la síntesis temporal, Buero Vallejo también reincide teatralmente en la formación heterogénea de la memoria activa mediante el solapamiento espacial sobre el tablado. En el escenario simultáneo que el dramaturgo concibe para El tragaluz convergen espacios dramáticos que, en realidad, no deben estar contiguos. Algunos ejemplos son el semisótano, la oficina de Vicente, la cafetería y el experimento de Él y Ella. Buero Vallejo se sirve, asimismo, de la luminotecnia, los efectos sonoros y 
la cinética para remarcar la calidad irreal de la anécdota. Esta última está basada en la realidad, pero procede de la memoria y de la fantasía. Al iniciar la escenificación del suceso intrahistórico capturado por su tecnología, "las ráfagas de luz van desapareciendo. En la oficina se amortigua la vibración luminosa y crece una viva luz diurna" (68-69). "La luz que ilumina a la pareja de investigadores es", por lo contrario, "siempre blanca y normal" (65), acentuando así su calidad actual - los experimentadores no proceden de la memoria como los personajes del pasado - en el juego temporal que se escenifica. La presencia escénica repetida de los "experimentadores", que "utilizan dos pequeños laterales que no distraen el decorado" (Oliva 249), pone de relieve el tamiz del experimento científico futurístico por el que pasa, sesgadamente, la anécdota. Mediante estas técnicas metateatrales, Buero Vallejo reincide en la capacidad utópica de la tecnología del futuro, capaz incluso de mediar en la formación de la memoria social.

La técnica cinematográfica de los fundidos ayuda, por último, a desdibujar los espacios dispares, incidiendo en el carácter subjetivo de la tecnología de la memoria cultural del siglo XXX. Gwynne Edwards ha señalado el efecto borroso del decorado y la luminotecnia al principio de cada escena, lo cual propicia una calidad fluctuante y onírica (semejante a las imágenes del cine mudo) al pasado representado. Los movimientos de los personajes corren paralelos a la luminotecnia, ralentizando y normalizándose a medida que la acción dramática avanza. Parecen adquirir vida paulatinamente, como si tuvieran que completar el proceso de cobrarla (Edwards 204-205). Por tal razón, el investigador del futuro advierte al público, antes de comenzar la dramatización de la anécdota, que "en este momento trabajan a rendimiento mínimo" los proyectores espaciales "y las figuras parecen inmóviles; actuarán a ritmo normal cuando les llegue su turno ... Os rogamos atención: el primer grupo de proyectores está llegando al punto idóneo..." (68). Mientras que los desplazamientos de Encarna y Vicente se vuelven normales cuando la acción dramática tiene lugar en la oficina, "en la penumbra del cuarto de estar El Padre y Mario se mueven de tanto en tanto muy lentamente" (69), como proyecciones fílmicas ralentizadas, hasta que Vicente se refiere a ellos, momento en el cual sus movimientos se aceleran. Como una película que por fin alcanza su ritmo normal, Buero nos introduce de lleno en una historia de la historia reciente con implicaciones universales, mientras que, simultáneamente, y de modo brechtiano, nos distancia de la misma, incidiendo así en su calidad de retentiva ficcional, aunque estribe en la memoria social de la Guerra Civil y sus secuelas.

Dos años después de la publicación y estreno de El tragaluz, un joven 
dramaturgo nacido en los años de posguerra, Jerónimo López Mozo, pasa a reconstruir y reivindicar este período en su obra titulada Guernica (1969), en donde se vale de una amalgama de recursos teatrales. ${ }^{6}$ Esta pieza es una especie de happening que promueve la improvisación por parte de los actores. Al contrario de un happening auténtico, Guernica consiste en un guión más o menos fijo, que hermana aspectos del Teatro Total de Piscator, el Drama Épico de Bertolt Brecht, y el Teatro Documental de Peter Weiss. ${ }^{7}$ El dramaturgo concede al público un rol activo en este happening, con asientos giratorios en 360 grados - "agrupados de tal forma que quedan pasillos y espacios amplios para el movimiento de los actores" (López Mozo, Cuatro 37) -, y un escenario innovador, quizás inspirado por Artaud, que coloca al espectador en el centro de la acción, desde el que pretende reproducir la emoción de "vivir" los bombardeos. De esta forma, el público contribuye, al igual que el autor y los actores (así como el relato imaginado de las figuras del cuadro insigne que estos dramatizan), a dar testimonio de la reconstrucción artística de la memoria colectiva del bombardeo de 1937, filtrado, claro está, por el lienzo de Picasso.

López Mozo se aprovecha de los testimonios auténticos, fotografías y hasta grabaciones de montajes anteriores de la misma obra, para mediar en la configuración de la memoria social del público. Alterna e imbrica recitaciones fidedignas e intertextuales desde los altavoces o voces en off, con múltiples proyecciones documentales sobre las pantallas que rodean al espectador. Incorpora, además, música e intervenciones líricas por parte de los actores, que dan vida a las figuras del cuadro de Picasso durante esta especie de ecfrasis escénica. Tal uso de audiovisuales sirve de "auténtico" testimonio para mediar en la formación de la memoria social del público.

Las susodichas voces en off también recitan varios versos insignes sobre España, la Guerra Civil, el Guernica de Picasso y otras contiendas que, sumados a las intervenciones líricas de algunos personajes, evocan una memoria literaria. Sumándose a los documentos audiovisuales, tales versículos mitifican la tragedia de este pueblo vasco. Parafraseando a Eileen Doll, Guernica constituye "una transposición múltiple y simultánea de tres sistemas de signos: el sistema del cuadro de Picasso, el de los textos poéticos escritos por otros y el del hecho histórico a través de películas documentales" ("Intermedialidad" 9). La trascendencia de este happening para la memoria universal se hace patente en su tono semejante al de una epopeya e, inclusive, en el programa de mano en el que se publican además de una imagen del cuadro de Picasso - versos que testifican los atropellos cometidos en contiendas posteriores a la Guerra Civil española. Entre estos, se destacan los de "España en el corazón" de Pablo Neruda, "Picasso" de Rafael Alberti, un poema escrito con ocasión de la Guerra de 
Corea por parte de un autor vietnamita, así como la Cantata de los Derechos Humanos de Norman Corwin. Tanto el lienzo de Picasso como la pieza de López Mozo sintetizan la memoria histórica y ponen de relieve su cariz dinámico y dilatorio. ${ }^{8}$

A la postre, convergen en Guernica las memorias históricas y artísticas de varias épocas, destacándose tanto las de la contienda civil española y de la realización de la pintura de Picasso, como las de la escritura de López Mozo. A esta confluencia se le suma las del tiempo en que viven los espectadores y las del futuro. Al igual que la obra de teatro Guernica (1961) de Fernando Arrabal, la pieza de López Mozo, centrada en elementos visuales, también manifiesta una dialéctica plástica, o ecfrástica, entre sendas obras de teatro y el cuadro de Picasso. Pero a diferencia de la inclusión ocasional y simbólica de imágenes plásticas derivadas del cuadro de Picasso en la pieza arrabaliana, la lopezmoziana dimana del cuadro de Picasso - que "llega a ser casi un personaje" en ella (Doll, "Intermedialidad" 10) -, incluso a nivel estilístico. Aparte de encontrarse en las páginas principales del programa de mano, el lienzo renombrado sirve de elemento central tanto al telón de fondo como a varios de los personajes y a algo de la acción. La función protagónica de dicho cuadro se acentúa en virtud de su presencia física sobre el escenario a lo largo del montaje "como el centro de todas las actuaciones, proyecciones y referencias intertextuales a composiciones poéticas y musicales sobre la destrucción del pueblo vasco durante la Guerra Civil" (Doll, Papel 145). ${ }^{9}$ Guernica vincula y actualiza las memorias históricas del bombardeo de 1937 y sus representaciones artísticas.

Al inicio de la pieza, los actores entran desde diversos puntos del teatro con piezas recortadas del célebre cuadro, a modo de un rompecabezas. Terminan unidos todos en una réplica del cuadro, al mismo tiempo que las voces en off documentan lo sucedido el veintisiete de abril de $1937 .^{10}$ Al animar a las figuras del cuadro de Picasso, López Mozo convierte a las víctimas nuevamente en "sujetos" de la memoria histórica y artística que representan. Como señala Mary Parker:

The piece could be described as art imitating art, or, more accurately here, as a theatrical collage that breathes new life into Picasso's painting denouncing the 1937 Spanish tragedy ... The criteria for this experiment may be life in historical art ... Guernika brings to life the visual static images in the painting ... Guernika mostly seems designed to show that in the performance, all art is organic, moves and lives on. (37)

Los parlamentos de los personajes - tales como el clamor de la Mujer del 
Incendio: "el fuego ha prendido mis ropas y mi carne. Grito desesperada" (López Mozo, Cuatro 96) - sirven para individualizar la cifra del número de muertos y heridos narrada por la Voz 1: "Entre los escombros y en el campo próximos yacían mil setecientos cincuenta y cuatro cadáveres y sufrían ochocientos ochenta y nueve heridos" (89).

Al final de la pieza, todos los personajes y la naturaleza personificada están ya muertos, salvo la encargada del parlamento final, la Portadora de la Lámpara. Este personaje, que atestigua la atrocidad perpetrada en Guernica, implora a los espectadores del siguiente modo:

Grito mi indignación, porque vuestras voces se pierden entre los escombros y son ahogadas por el estruendo de las bombas. Recorro la ciudad. Ilumino cada rincón buscando los triunfos de la muerte... Cuando la noche os cubra, mi lámpara seguirá encendida señalando al mundo el lugar en que se ha consumado el crimen. Ninguno puede ignorar mi denuncia. Transmitidla cuantos estáis aquí. Evitad que los hogares sean destruidos por el fuego. Lamentad que los hijos mueran asesinados en los brazos de sus madres. Este que agoniza retorciéndose de dolor es un pueblo inocente. Encended vuestras antorchas y mantenedlas así mientras en el mundo los pueblos sean destruidos y sus gentes matadas. (103)

Su función es la de iluminar las memorias colectivas de aquella brutalidad cometida contra el pueblo de Guernica con el fin de evitar su repetición. Por ello, exige al público que se una a los actores y encienda sus cirios, símbolos del compromiso de todos con las memorias históricas de Guernica. Esto viene a ser otro ejemplo de cómo el happening pluraliza la memoria de la tragedia acontecida. En resumen, el dramaturgo revive, contrapone y relaciona estas memorias sociales y artísticas para contribuir a su perpetua revisión.

Por su parte, el texto teatral de estilo heterogéneo del exiliado español José Antonio Rial, La muerte de García Lorca (1969), destaca lo mudable de la memoria histórica en varios niveles. Intercala escenas narrativas en las que polemizan tres historiadores auténticos - Couffon, Gibson y Schonberg - acerca de la muerte de Federico García Lorca el 18 de agosto de 1936. Influenciadas por el teatro de Brecht y de Weiss, estas discusiones sobre los documentos históricos, entretejidas con proyecciones y grabaciones de entrevistas a varios testigos oculares - además de otras escenas surreales, intertextuales, metafísicas y metateatrales -, conducen al público a poner en tela de juicio las distintas representaciones "realistas" de la muerte de Federico García Lorca."

A pesar de ello, el presunto mediador de la discusión entre los tres his- 
toriadores, el Relator, no es, en rigor, objetivo, sino más bien un portavoz de Rial, de manera que se inclina a favorecer la perspectiva de Gibson. Cuando este pregunta "por qué entre los muchos testigos que podrían traerse han elegido al señor Schonberg" - quien, pese a las pruebas en contra, "intenta sostener que éste no fue un asesinato político" -, el Relator responde: "Sí, podríamos haber traído muchos otros testigos, pero con ellos no habría entrado en cuestión el tema Schonberg ... Schonberg viene a probar que se quiso justificar el crimen mediante la infamia de sugerir que Federico tuvo la muerte que merecía. Lo han gritado: 'Lo matamos por maricón”" (Rial 26). Tal parcialidad suscita la indignación de Schonberg, quien prorrumpe en una ocasión: “iProtesto! ¿Qué puedo decir ya que me sea aceptado por un público que sufre abierta coacción?" (19). Al amenazar con dejar el escenario, el Relator le replica: "No se puede usted ir. Su libro está escrito y no se borra ni se quema solo" (26). Al fin y al cabo, todos somos responsables de lo que hacemos y de lo que escribimos, sobre todo si pretendemos que se lo considere documento histórico. No podemos cambiar el pasado, solo reevaluarlo.

La pieza también abarca la memoria y el olvido colectivos de manera metateatral. A modo de ejemplo, el personaje Tramoyista Jefe despoja del escenario cualquier decorado que disimule la represión brutal del bando Nacional: "Fuera con este piano, con esos árboles, esas flores. Hay que limpiar todo lo que recuerde, sugiera..." (17). Esto da pie al "escenario intemporal, objetivo, casi neutro" que ocuparán, a renglón seguido, los tres historiadores y el Relator. Inclusive intervienen simbólicamente algunos personajes ficcionales, procedentes de la obra dramática de García Lorca. En la escena titulada "Sueño de Federico", se representa un "trasmundo" en el que participan "el cuerpo desnudo y blanco de Mariana Pineda y maniquíes vestidos de Bernarda Alba y doña Rosita" (59). Al intervenir el títere Cristobita, confluyen la farsa, lo surreal, la ficción y la realidad:

(Mientras grita se cumple el ceremonial de ejecutar a Mariana Pineda en el garrote vil, música de fondo de 'Canción de las Niñas' de 'Mariana Pineda') ‘Vivan las cadenas!' ‘Dios, Patria y Rey!' ‘Por el Imperio hacia Dios!' ‘Arriba España!' (Cantando con voz histérica sobre la música de 'Mariana Pineda') 'Cara al sol / con la camisa nueva... / Cara al sol / con la camisa nueva...' (Como un disco rayado sigue.) 'Cara al sol / con la camisa nueva...' (El 'Pajarero' y Trescastro colocan a Mariana en el garrote, que está ahora frente al público. Aparece por la derecha Ramón Ruiz Alonso, con sotana, rostro azul y un rollo de papel en la mano, se dirige a Queipo.) (61)

Acto seguido, el General Nacional Queipo de Llano ejecuta a Mariana Pineda a garrote vil, fusionando así momentos bélicos de los siglos XIX y 
XX de la historia española.

De igual modo, la memoria literaria se introduce y confluye en la acción dramática de modo bastante inverosímil mediante algunos poemas lorquianos. Los tres historiadores pronuncian sus versos - discutiendo cuáles son los fundamentales - o estos se oyen por medio de altavoces en el momento en el que se pone en escena lo descrito líricamente. Por ejemplo, durante la detención de Lorca, se recita a través del Altavoz: "por las calles empinadas / suben las capas siniestras / dejando atrás fugaces / remolinos de tijeras" (24). Con frecuencia el personaje del poeta granadino se desdobla en un doble menor: un Lorca de 1936 que lee un poema suyo escrito el día de su muerte con motivo de su despedida del homólogo de 1920 - la fecha en la que auguró su propia muerte. Y no hay que olvidarse de que los actores que encarnan a Lorca devienen espectros procedentes de la memoria, puesto que La muerte de García Lorca fue protagonizada por un personaje histórico. Es decir, ya que Lorca proviene de la vida real, el personaje que lo representa sobre el escenario sería un fantasma resucitado, acorde con alguna memoria del poeta auténtico.

El personaje de Lorca también reivindica su poesía nada más encontrarse en la presencia de otros tres presos, de otras víctimas del odio y del poder desenfrenado. En la cárcel, al encontrarse con la belleza de "los rostros humanos" de las tres víctimas anónimas, y "arrastrado por el poema, recita": "Pero los muertos son más fuertes y saben devorar pedazos de cielo" (54). El poeta reconoce que, a largo plazo, las memorias intertextuales captadas en sus poemas sobre las víctimas triunfarán sobre la versión oficial impuesta por el poder. Esta conclusión concuerda con el planteamiento de Winter y Sivan, quienes han comentado que, con el paso del tiempo, la voz doliente de las víctimas termina sobresaliendo en relación a la de los vencedores (36). Como se observa en España hoy por hoy, la memoria de las víctimas termina imponiéndose con respecto a la versión oficial de la época - si bien sigue habiendo refutaciones considerables por parte de los herederos del bando vencedor. ${ }^{12}$

Las memorias de la cultura también prevalecen, ya que el objetivo de los franquistas de aniquilar obras de arte que no concordaran con su ideología no dio resultado. Antes de su detención, Federico cuestiona líricamente su oficio mediante la personificación del Odio que "mira fijo a Federico":

El Odio. - ¿Qué poeta soy que han tenido que echarle mano al cuello de los míos y meterme los dedos en los ojos y hasta en el culo, para que me diera cuenta de que rebosa por encima de España y echa espumarajos en sus tres mares? ... yo andaba abrazo aquí, y dedicatoria allá, sin hiel, ciego, ¡maldita sea! Y todavía escribiendo de 
encajes de bolillo, de cintas liberti, de agremanes de seda, de confituras, de palomillas de anís, de huesos de santa Catalina, etc., mientras ellos ... encargaban ametralladoras ... No habrá peor muerte que ésta que sufro ya. Reniego de todos mis lirismos, de tantas flores, de magnolias a alhelíes, de rosas a mirtos, como he estado deshojando en esos libros que me duelen más que estos huesos que me van a romper a tiros. $\left(\mathrm{Rial}_{3} 8\right)$

Según el poeta, el Odio perpetrado por los franquistas ha suprimido sus versos, los mismos que Federico considera poco eficaces al favorecer la belleza irreal sobre la cruda realidad del rencor que se propagaba por España. Su poesía, eso sí, superó la ideología franquista a largo plazo en virtud de su reconocimiento a nivel tanto nacional como internacional.

Pero la memoria de Lorca también se impone por haberse convertido en mito. Según Jan Assman, la Historia se convierte en mito en cuanto se recuerda, se narra, se usa, es decir, en cuanto se entreteje en la construcción del presente, desarraigándose, en consecuencia de su contexto histórico (Olick et al. 210). Se relaciona, además, con lo divino. Efectivamente, el protagonista exhibe una inquietante capacidad de prever el futuro. Y la última foto de Lorca y sus amigos artísticos parece una réplica, en cierto sentido, de la última cena de Jesús. En una escena surrealista y simbólica, a su vez, la coronación y tortura de Lorca por parte de "los amigos con cabezas de jabali" alude a la pasión de Cristo. Al contrario del propio Rial, los Jabalíes/Fascistas perciben la Historia como una fuerza omnipotente que actúa sobre el individuo: "Es la Historia. ¿Crees que se puede jugar con...? Mírala. Ahí se precipita. Incontenible" (Rial 16).

Rial, en cambio, está abocado a cuestionar, inclusive, el estudio de la Historia en general. De modo lúcido, el dramaturgo asegura en 1978: "es el momento de volver y de contar a los españoles lo que no han podido saber de su pasado inmediato porque ha habido una manipulación increíble de la historia" (4). En efecto, el autor hace hincapié en la subjetividad de la Historia, que depende de la ideología de los que disfrutan del poder. Pone en entredicho, asimismo, las polémicas superficiales entre los tres investigadores, a saber la que discute sobre la ropa que llevaba Lorca el día de su muerte, mientras que los tres historiadores hacen caso omiso de las cuestiones más trascendentales, como el motivo de su persecución intelectual. En una ocasión, el Relator les advierte a los tres: "Señores, pueden ustedes discutir lo importante, pero si van a disputar por detalles nimios..." (25). Al final de la pieza, "cuando el público comienza a levantarse y a salir, se alza de nuevo el telón y aparece todo el desorden del Sueño, y los Tramoyistas cargando objetos diversos" (64). Entretanto, el Relator recalca 
la futilidad del debate sobre la veracidad de detalles históricos insustanciales: "Tres de nosotros, convencidos de que la barbarie ha de suprimir a la inteligencia, porque éste es su sino y su fiesta bruta de suicida, no logramos acuerdo, a causa de una simple cuestión de detalles: de si el poeta vestía un pijama o si cenó tortilla la última noche ¿comprenden? Discutíamos sobre..." (64). Con todo y eso, Rial limita la autonomía de los tres historiadores, por lo que los Tramoyistas hacen caso omiso de Gibson, Schonberg y Couffon cuando estos se empeñan en argumentar el final de la pieza y en exhortar a los tramoyistas que no desmonten el decorado. A fin de cuentas, la puesta en escena, si bien promueve la recuperación de la memoria histórica, tiene que patentizar el punto de vista particular del autor.

En suma, la alternancia de planos quiméricos, intertextuales, metafísicos, y meta-documentales brinda al espectador una memoria colectiva íntegra y voluble de aquel momento histórico del que el público será el último juez. Así, por ejemplo, después de leer un poema sobre la homosexualidad, Couffon interroga "al teatro": "Señores, ¿seríamos capaces de condenar ahora mismo a muerte a los pederastas que están aquí entre nosotros, porque escriban poemas o por el simple delito de serlo?" (34). Conviene subrayar que los investigadores, eso sí, ayudan a moldear el juicio de los espectadores. Efectivamente, será Gibson quien pida a la audiencia que oiga "la grabación" de su entrevista con Ruiz Alonso. En la misma, se descarta "la versión popular" que se acaba de poner en escena, en la que Ramón Ruiz Alonso reclamaba el fusilamiento de Lorca para desquitarse del presunto asesinato de don Jacinto Benavente: "No defiendo a Ruiz Alonso, pero me gustaría que el público se formase un criterio de la persona, según un texto fidedigno" (34). El Relator, como representante de los intereses de Rial, permite la transmisión de la grabación después de escenificar la detención de Lorca:

A telón corrido, la grabación, que ha de transmitirse a todo el teatro, incluso al exterior del mismo, ya que se oye durante el entreacto. La escena puede acompañarse con película proyectando en pantalla la escena de Ruiz Alonso, declarándole a Gibson, con algunas secuencias alternadas del grabador oculto registrando el diálogo. (44)

Pero, en última instancia, insistimos en que será el público quien, valiéndose de los documentos escenificados y de su interpretación teatral, tenga que decidir cuál es la memoria histórica más convincente: “¿La España que le odiaba condenó a muerte al poeta que acusaba de homosexual o al que acusaba de poeta?" (Rial 26). Por otro lado, habría que reconocer la aseveración del Relator que "por mucho que investiguemos 
los detalles, creo que nunca sabremos la verdad" (51). Hasta cierto punto resulta imposible desembrollar minuciosamente toda la realidad en relación con la muerte de Lorca, pero eso no significa que haya que abandonar la investigación y la modificación de la memoria colectiva al respecto. Al contrario, como advierte Hutcheon, hay que aceptar la coexistencia de las verdades en plural (109). Gibson afirma "El 'muera la inteligencia' no es un hallazgo casual. Es un grito hondo y va a repetirse. ¿Qué digo? Se repite en América, en Asia, en África ... aquí, en esta Europa... Se ha repetido. No olvidemos nombres. Y lo peor: ese 'muera la inteligencia' sigue vigente, sigue en pie" (51). De ahí lo imprescindible de la revisión asidua de la memoria colectiva para evitar que se repitan los aspectos nefastos del pasado en el porvenir. La súplica final de Gibson reza: "Juicio sumarísimo y pena capital contra todo poeta, contra todo artista, contra todo el que ... (Se lleva las manos a la cabeza.) Inconcebible, pero era de esperar (Al público.) ¿Habrá cómo impedirlo?” (65). Sobre las tablas se funden, en resumen, la memoria literaria, documental y testimonial con intención de plasmar una memoria colectiva mucho más íntegra del funesto asesinato de uno de los mejores autores españoles. Resulta evidente que Rial se aprovecha de un sinfín de recursos teatrales y metaliterarios para incitar al espectador a cuestionar las memorias históricas de 1936 y la forma en que estas inciden en su perspectiva actual.

En conclusión, las memorias sociales del presente, del pasado y del futuro confluyen, y se examinan, en estas tres obras que auguran un estilo nuevo entre la dramaturgia española sobre la Guerra Civil: el de la metamemoria histórica. Esto se ha logrado mediante la confrontación teatral y el manifiesto cuestionamiento de claroscuros polifacéticos asociados con las representaciones de una época del pasado y las memorias colectivas de otro momento contemporáneo. El objetivo del recurso dramático es seguir consultando y examinando todas las vertientes de las memorias sociales relacionadas con aquella contienda. Esta estética ha cobrado cada vez más relieve en el teatro español a medida que se ha ido tanteando dicho pasado traumático en España a lo largo del último medio siglo. Se podría afirmar que, en el siglo XXI, esto será una tendencia entre algunos dramaturgos que heredaron su memoria, o post-memoria (si usamos el término de Marianne Hirsch), entre los que se destacan López Mozo, Laila Ripoll, Juan Mayorga, Raúl Hernández Garrido, José Luis Alonso de Santos, Maite Agirree Itziar Pascual, entre otros. ${ }^{13}$ Pero habrá que recordar que fueron Buero Vallejo, López Mozo y Rial los que, en las postrimerías del franquismo y con amplias restricciones para escribir, se adelantaron a su época con tres piezas fundamentales. Dieron inicio así a esta estética que 
es privilegiada entre las piezas más destacadas de la dramaturgia actual sobre la Guerra Civil.

Providence College

\section{NOTAS}

$1 \quad$ Los protagonistas de Seis personajes en busca del autor (1921) del dramaturgo italiano, Luigi Pirandello, también reivindican las historias de sus vidas, pues solicitan al autor que las escriba.

2 En su "Taller de lectura", Ana María Platas Tasende usa el término de analepsis del segundo grado (las rememoraciones de la familia de momentos anteriores a 1967) dentro de analepsis del primer grado (el del año 1967 que originan los investigadores del siglo XXX) (Buero Vallejo 206). Consideramos que la memoria dentro de la memoria cultural es más inclusiva y no tan específica, razón por la cual elegimos este término.

3 Durante el "juicio" final, Mario confiesa a Vicente que fue otra víctima suya: “También aquel niño que te vio en la ventanilla del tren es tu víctima. Aquel niño sensible, a quien su hermana mayor enseñó de pronto, cómo era el mundo" (162).

4 Como deduce Mariano de Paco, "dentro del problematismo individual que la esperanza trágica siempre encierra, [El tragaluz] se trata de un drama esencialmente optimista por su propia concepción dramática, porque los Investigadores provienen de un tiempo y de un lugar en los que ya se han superado numerosas deficiencias actuales" (186; énfasis en el original).

5 Buero Vallejo explica en la acotación que da entrada a la pieza que, "cuando los personajes miman el ademán" de abrir el tragaluz, "proyecta sobre la estancia la sombra de su reja" (64).

6 Guernika es una de las obras de López Mozo más conocidas mundialmente, además de ser el happening más traducido y publicado del dramaturgo (Doll, Papel 106). La fijación de este autor y otros dramaturgos españoles nacidos después de la Guerra Civil con el tema de este trauma vivido por parientes suyos da fe de la teoría de la "postmemoria" de Marianne Hirsch, la cual sugiere que las secuelas de un trauma colectivo son traspasadas a la segunda y tercera generación si la primera generación no resulta capaz de lidiar con esto. A pesar de no haberlo vivido en carne propia, los hijos y nietos de las víctimas con frecuencia "rememoran" el trauma, como si lo hubieran vivido ellos mismos (111).

7 En 1975, López Mozo aseveró "la palabra happening que yo empleo tiene poco que ver con el significado real. Hablar de happening en España es absurdo, 
puesto que su existencia no es posible desde el momento en que las normas de censura exigen que los textos sometidos a su consideración sean definitivos, lo que elimina toda posibilidad de la improvisación. Por otra parte, el teatro ha de ser representado obligatoriamente en un escenario y no en otro local". Afirma creer "en el happening en cuanto elemento incorporable a [su] teatro, pero no como finalidad en sí mismo. Resumiendo, el happening para [López

Mozo] es un guión sobre el que los actores deben improvisar durante los ensayos como medio para construir el espectáculo definitivo" ("Guernica [happening]" 18).

8 Doll describe un estreno actualizado con respecto a la trascendencia universal de Guernika por parte de López Mozo. En su Monólogo de la mujer que mira la luz (2003), el dramaturgo pone al día una parte de su obra de 1969 -

evidentemente la del parlamento de la Mujer que mira la luz - que ya no alude a la guerra norteamericana de Vietnam, sino que acentúa la relación de Guernica con la guerra de los Estados Unidos contra Irak. Entretanto, el autor "moderniza su manera de utilizar la pintura de Picasso como escenario. En vez de construir el cuadro en escena, lo destruye, tiñéndolo de sangre, todo a base de proyecciones, un recurso más tecnológico. En una fragmentación postmoderna, López Mozo descompone el cuadro Guernica en sus bocetos y extrae una figura en particular que convierte en la Mujer iraquí. Esta vez, el cuadro no preside silenciosamente, sino que sufre igual que las víctimas humanas" (Doll, Papel 126).

9 Según Doll, "en un artículo reciente, José Luis Campal Fernández asegura que 'López Mozo, durante la escritura de su happening, tuvo delante de sus ojos el lienzo, a pesar de estar prohibida su reproducción en España', pues su padre lo había reproducido ('Violencia política'). Esta urgencia de tener el cuadro prohibido presente refleja la misma urgencia transmitida por su presencia en escena" (Papel 107).

10 Como percibe John Kronik, "the painting, when not viewed as a total unit, is a series of pictures, each with a life of its own, that permit a 'reading' of the painting - a linear progression in space and time from left to right" (19). A lo largo de la pieza, López Mozo disgrega estas imágenes que conforman la "lectura" de la pintura, las imbuye una voz autónoma a cada una, para luego reunirlas de nuevo.

11 Es curioso que el estilo del dramaturgo exiliado en los años 6o esté actualmente en boga entre la novela española de metaficción historiográfica escrita por Javier Cercas, Isaac Rosa e Ignacio Martínez de Pisón, entre otros. Según Ulrich Winter, sus novelas se empeñan “a través del documentalismo, en la producción de realidad o de presencia del pasado, esto es, en presentar la misma realidad histórica a la vez que se la representa literariamente" (254). 
I2 Pensamos en el fallo por parte del Tribunal Constitucional a favor de la devolución de los "papeles de Salamanca" a Cataluña (2013) y la aprobación de la Ley de la Memoria Histórica (2007), pero también en la oposición al cumplimiento de la misma y en la condena del Juez Garzón (2012).

\section{OBRAS CITADAS}

ALPhEn, ERnest VAn. "Symptoms of Discursivity: Experience, Memory, Trauma". Acts of Memory: Cultural Recall in the Present. Eds. Mieke Bal, Jonathan V. Crewe y Leo Spitzer. Hanover: UP of New England, 1999. 24-38.

BUERO VAlLejo, ANTONio. El tragaluz; experimento en dos partes. Eds. Virtudes Serrano y Mariano de Paco. Madrid: Espasa Calpe, 2002.

CAR U TH, CA THY. Literature in the Ashes of History. Baltimore: John Hopkins UP, 2013.

DER RIDA, JA C Qu Es. Espectros de Marx. Trad. José Miguel Alarcón y Cristina de Peretti. Madrid: Trotta, 1998.

D O L, EI L E N. El papel del artista en la dramaturgia de Jerónimo López Mozo: juegos temporales e intermediales. Madrid: Iberoamericana, 2008.

—. "La intermedialidad del teatro de López Mozo: de lo visual a lo textual". Estreno 27.2 (2OOI): 8-I5.

EDWAR DS, GWYN E. Dramatists in Perspective: Spanish Theatre in the Twentieth Century. Cardiff: U of Wales P, 1985.

FÉRAL, JOSETTE. "La memoria en las teorías de la representación: entre lo individual y lo colectivo". Teatro, memoria y ficción. Ed. Osvaldo Pellettieri. Buenos Aires: Galerna, 2005. 15-30.

FINK, BRUCE. "Fantasías y el fantasma fundamental: una introducción". Virtualia. Revista Digital de la Escuela de la Orientación Lacaniana I3 (2005): 2-Io.

ha biwachs, mau rice. On Collective Memory. Trad. Lewis A. Coser. Chicago: Chicago UP, 1992.

hi R SC H, MA RiAn n. Family Frames: Photography, Narrative and Postmemory.

Cambridge: Harvard UP, 1997.

hutCheon, Linda. A Poetics of Postmodernism: History, Theory, Fiction. New York: Routledge, I988.

IGLESIAS FEIJO0, LUIS, ED. Introducción. El tragaluz. Por Antonio Buero. Madrid:

Espasa Calpe, 1993. 9-59

KRONIK, JOH N W. "Arrabal and the Myth of Guernica". Estreno 2.I (I976): 15-20.

Ló Pez M OZo, Jerón Im o. Cuatro happenings. Ed. Ricard Salvat. Murcia: Universidad de Murcia, I986.

— “Guernica (happening)”. Estreno I.I (I975): I9³I. 
ME DiNA VICARIO, Miguel. Veinticinco años de teatro español (1973-20oo). Madrid:

Fundamentos, 2003.

MuÑ O Z CÁliz, Berta. Censura y teatro del exilio. Murcia: Editum, 2010.

No RA, PIE RRE. "Between Memory and History: Les Lieux de Mémoires". Trad. Marc

Roudebush. Memory and Counter-Memory. Número especial de

Representations 26 (1989): 7-24.

OLICK, JEFFREY K., VERED VINITZKY-SEROUSSI y DANIEL LEVy. The Collective

Memory Reader. New York: Oxford UP, 2OII.

OLIVA, CÉSAR. El teatro desde 1936. Madrid: Alambra, I989.

PACO, MARIANO DE, ED. Estudios sobre Buero Vallejo. Murcia: Universidad, 2000.

PAR KE R, MARY, E D. Modern Spanish Dramatists: A Bio-bibliographical Source Book.

Connecticut: Greenwood, 2002.

Pirandello, Luigi. Seis personajes en busca de autor. Madrid: Edaf, 200 I.

RIAL, José ANT ONIO. "La muerte de García Lorca". Pipirijaina 7 (1978): I-65.

RicoE UR, PAUl. La memoria, la historia, el olvido. Buenos Aires: Fondo de Cultura

Económica, 2004.

rotman, B RiAn. "Automedial Ghosts". Profession. New York: MLA, 20II. II8-i22.

RUIZ RAM ÓN, FRANCiS Co. Historia del teatro español; siglo XX. Madrid: Cátedra,

1997.

WINTER, ULRICH. "De la memoria recuperada la memoria performativa. Hacia una nueva semántica cultural de la memoria histórica en España a comienzos del siglo XXI". Docuficción: enlaces entre ficción y no ficción en la cultura española actual. Eds. Christian von Tschilschke y Dagmer Schmelzer. Madrid:

Iberoamericana, 20IO. I49-I64.

Winter, Jay, y emmanuel Sivan. "Setting the Frameworks". War and

Remembrance in the Twentieth Century. Cambridge: Cambridge UP, I999. 6-39. ZEMON DAVis, NATAlie, y RAndolph StaRn. "Memory and Counter-Memory".

Representations 26 (I989): I-6. 